\title{
Analytical tools for assessing the information and telecommunications sector of the Russian regions
}

\author{
Elena Fokina \\ Volgograd State University, \\ Institute of Management and Regional Economics \\ Volgograd, Russia \\ fokina-ea@mail.ru
}

\author{
Anna Trukhlyaeva \\ Volgograd State University, \\ Institute of Management and Regional Economics \\ Volgograd, Russia \\ ann.tru@mail.ru
}

\author{
Viacheslav Shchekochikhin \\ Volgograd State University, \\ Institute of Management and Regional Economics \\ Volgograd, Russia \\ scvv@mail.ru
}

\begin{abstract}
The analysis of the main vectors of the development of the information and telecommunications sector is objectively conditioned by the results of market transformations, the increasing role of technological and information support of various segments of the economy at the national level. The article presents the results of assessing the level of development of the information and telecommunications sector of the Russian regions. Determining the level of information and telecommunications development in the constituent entities of the Russian Federation requires the development of analytical assessment indicators that reveal priority areas and constraints at the regional level. The following groups of factors are presented in the study: indicators of the level of human potential provision; indicators of the level of use of information and telecommunications technologies. The multidimensional data array was processed using the analytical platform Deductor Academic. The study was conducted on the basis of the construction of an aggregate indicator used to assess the regions of the Russian Federation in terms of the level of development of the information and telecommunications sector of the economy. The spread in the values of indicators for the main blocks is revealed, which generally determines the significant interregional differentiation. A complex of typological groups of regions was formed in accordance with the rating of the development level of the information and telecommunications sector. The practical significance of the results obtained is that they can be used to carry out transformations in the sphere of strategic territorial management in order to improve the performance of the information and telecommunications sector of the economy. The direction of future research is the adaptation of multidimensional classification methods to the study of the information and telecommunications sector of the Russian economy.
\end{abstract}

Keywords - information and telecommunication sector of the economy, interregional differentiation, evaluation methodology, data warehouse

\section{INTRODUCTION}

The information and telecommunications sector is one of the possible points of economic growth in the Russian Federation. The development vector of the information and telecommunications sector is formed in accordance with the set of its basic elements, as well as state concepts and programs of the federal level in the field of high technology development, including in the information and telecommunications sector. The state program of the Russian Federation "Information Society (2011-2020)" [1] provides for the development, widespread adoption and use of modern information and telecommunication technologies by citizens, business, state and municipal authorities. The strategy for the development of the information technology industry in the Russian Federation for 2014-2020 and for the future up to 2025 [2] was developed taking into account the provisions of the Innovation Development Strategy [3], which provides for a unified system approach to the development of the information and telecommunications sector. In addition, the adopted Information Society Development Strategy until 2030, as the main direction of improving the country's economy considers precisely the information and telecommunications sector [5]

The technical, technological, organizational and managerial changes occurring in modern conditions related to the dissemination of information and telecommunication technologies cover practically all spheres of economic activity, which determines the urgency of assessing the dynamics and prospects for the development of this sector.

In connection with the presence of these changes in this paper, the goal is to assess the regions of Russia in terms of the level of development of the information and telecommunications sector. 


\section{MATERIALS AND METHODS (MODEL)}

To assess the development of the information and telecommunications sector, the authors proposed a methodology based on the following theoretical provisions: the information and telecommunications sector, its evaluation is based on three interrelated basic factors (telecommunications, information technology, human development); composition and number of factors determines the specifics of the development of the information and telecommunications sector of the Russian economy. In the system of indicators, the priorities of the characteristics of the information and telecommunications sector are shifted from ensuring the availability of communication facilities, networks and ICT, that are characteristic of the first stages of informatization, the progressiveness of the information and telecommunications infrastructure, and the intensity of ICT use.

The system for assessing the level of development of the information and telecommunications sector includes indicators integrated into three consolidated groups (fig. 1.).

Each group of factors $N_{i}$ contains primary indicators $n_{i j}$, which determine the aggregate index of the group from different positions.

Assessment of information and telecommunications development (state, dynamics and potential) of the subjects of the Russian Federation requires analytical processing of primary indicators for the period from 2011 to 2015 [4].

At the initial stage, a rating scale is constructed based on the use of the scale interval method and assignment of rating points for each indicator.

At the next stage, the aggregate indicator $\left(I_{A l i}\right)$ for information, telecommunication factors and the human capital factor is calculated, and the rating of regions is calculated on the basis of the additive scheme:

$$
I_{A I i}=\sum_{j=1}^{n} P_{i j}
$$

where $P_{i j}$ - the rating of the region by a separate factor, $i$ - the number of the region, $j$ - the number of the indicator.

Eight federal districts and 83 constituent entities of the Russian Federation were included in their research: 47 regions, 21 republics, 9 territories, 1 autonomous region, 3 autonomous areas and 2 cities of federal significance (Moscow, St. Petersburg).

The system of indicators for the evaluation of the information and telecommunications sector is intended not only for more objective measurement, detailing or comparison of development levels, but it can also serve as a methodological tool for monitoring the dynamics of changes in the ICT sector at various levels of the economy.

The information and telecommunication sector is characterized by a complex structure of technological, economic and organizational-network character, high dynamism of changing the parameters of the market environment and conjuncture.

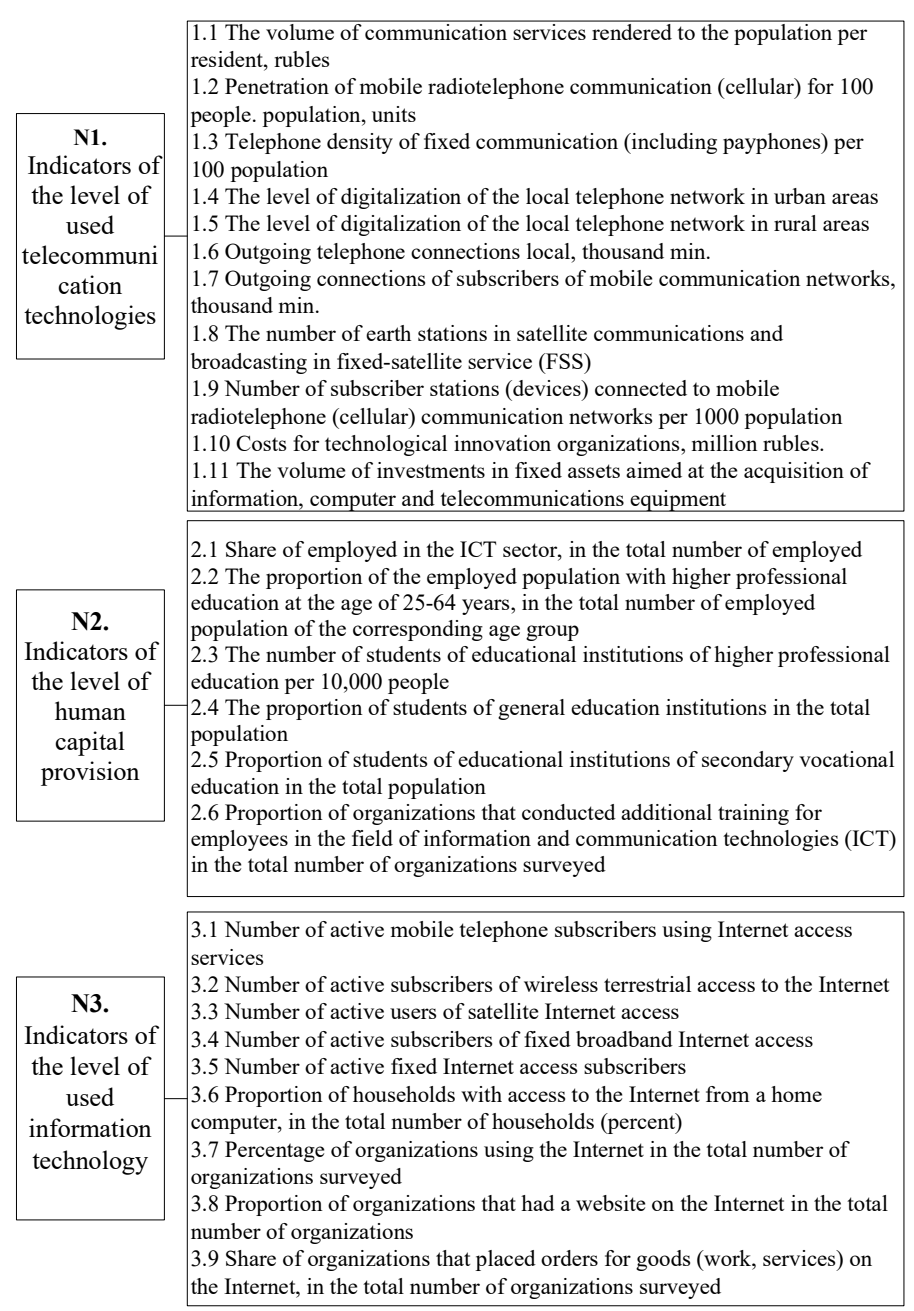

Fig. 1. Indicators for assessing the level of development of the information and telecommunications sector

In this connection, for its generalized analysis, the aggregate indicator, methods of comparative analysis and rating evaluation are used.

The formal-mathematical method for determining the number of groups of regions involves the use of the Sturgess formula:

$$
n=1+3,322 \lg N=\log _{2} N+1
$$

where $n$ is the number of groups, $N$ is the number of regions analyzed.

The value of equal intervals of the values of the indicator is determined as follows:

$$
i=\frac{x_{\max }-x_{\min }}{n}
$$

where $i-$ is the value of the indicator interval,

$x_{\max }$ - the maximum value of the indicator by region,

$x_{\min }$ - the minimum value of the indicator by region. 
To create an information-analytical representation of the level of development of the sector in question, a data warehouse developed by means of the analytical platform Deductor was designed, in particular, with the help of one of its components, the specialized software Deductor Warehouse.

\section{RESULTS AND DISCUSSION}

The construction of the aggregate indicator was carried out on the basis of rating technology in the context of territorial entities.

As a result, it was found that Moscow $(\mathrm{AI}=95)$, St. Petersburg $(\mathrm{AI}=80)$ has stably high values for the aggregate indicator in 2015, followed by the Tyumen Region $(\mathrm{AI}=79)$, the Sverdlovsk Region (AI = 75), Khanty-Mansi Autonomous Area $(\mathrm{AI}=73)$, Republic of Tatarstan $(\mathrm{AI}=72)$.

However, it should be noted that for the analyzed period from 2011 to 2015 there is some improvement in the positions of the subjects of the Russian Federation. Positive shift in the rating for 2015 compared with 2011 is noted in the Sverdlovsk region from 7 th to 4 th place ( 3 positions), in the Krasnodar Territory from 18th to 12th place (6 positions), in the Krasnoyarsk Territory from 17 th to 8 th place (9 positions ). In general, the obtained data testify to the different speed and scale of the development of the information and telecommunications sector, due, inter alia, to the difference in the socioeconomic level of development and the state of the personnel potential of the regions of the Russian Federation.

The regions of the Central and Volga Federal Districts demonstrate a steady effect in increasing the aggregate indicator of human potential for 2015. In the group of outsiders in the ratings for the results of 2014-2015. no significant changes occurred, this group is represented by the regions of the Southern Federal District. The main contribution to the aggregate indicator for the human factor is made by the Central, Volga and Siberian federal districts (Figure 2). In 2015, the values are respectively equal to 197 (19.28\%), 191 (18.69\%), $156(15.26 \%)$.

The resulting estimation for the telecommunication factor is presented in Figure 3. High values of the aggregate indicator are observed in the Central (380 points), Volga (338 points) and Siberian (266 points) federal districts. However, the dynamics of the latter two are not positive. A clear outsider for this factor is the North Caucasian Federal District (77 points).

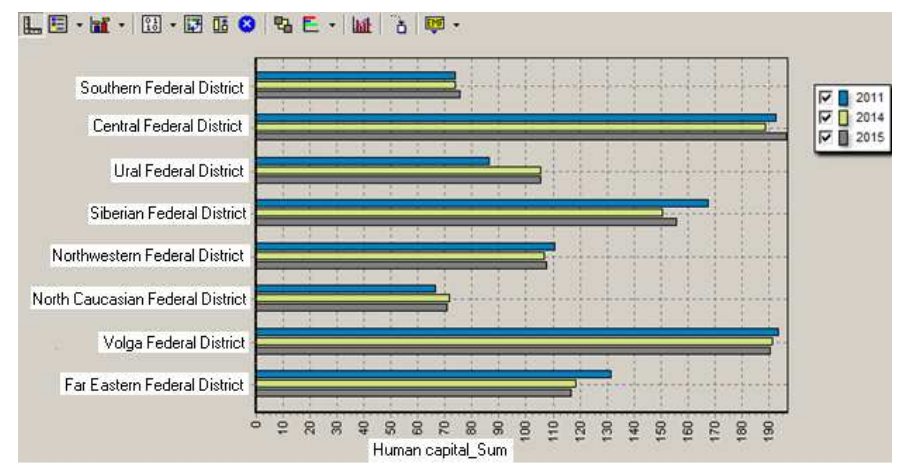

Fig. 2. Dynamics of the aggregate indicator for the human factor by federal districts
There was a decrease in the final telecommunications indicator for the Southern Federal District from 115 points to 106 points.

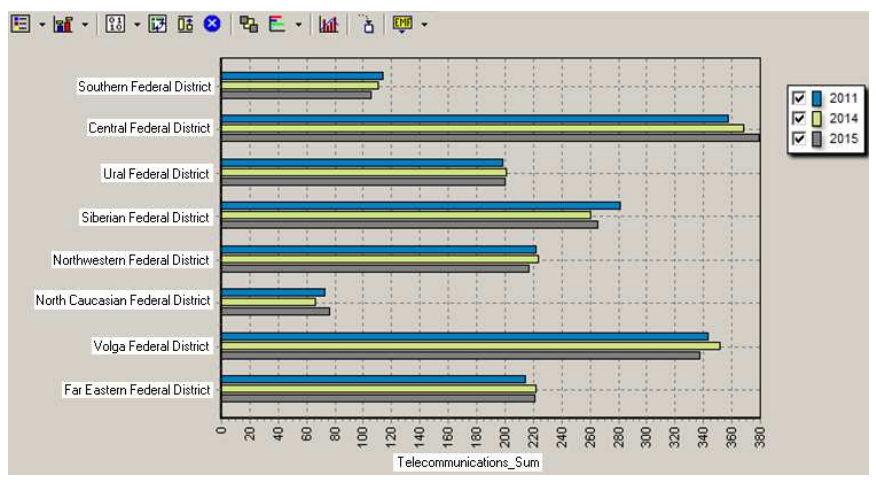

Fig. 3. Dynamics of the aggregate indicator for the telecom factor by federal districts

The greatest value of the aggregate indicator for the information factor for 2015 is noted in the Central - 340, Volga - 282 points in the federal districts. The least important is the North Caucasian Federal District - 65 points (Figure 4). In the Southern Federal District, this indicator decreases for the period under study: 2011 - 111 points, $2014-94$ points, 2015 - 90 points.

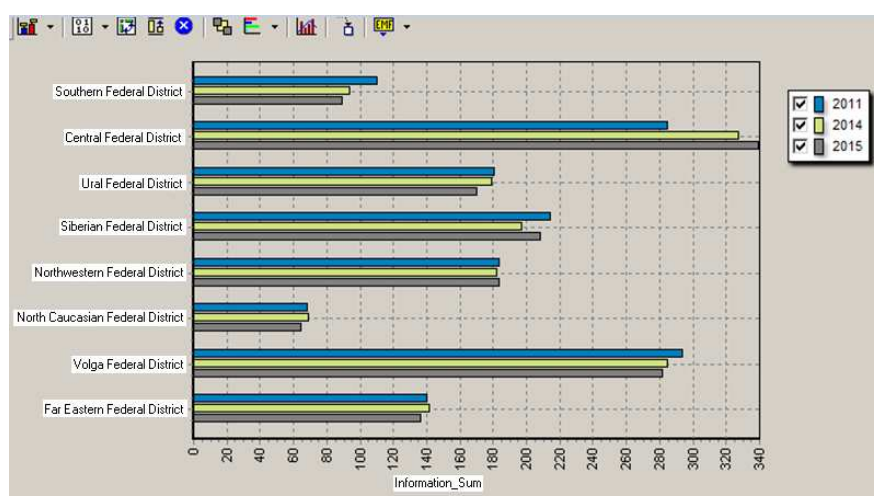

Fig. 4. Dynamics of the aggregate indicator for the information factor by federal districts

As follows from the diagram of the distribution of the aggregate indicator of the level of development of the information and telecommunications sector by federal districts (Figure 5), the largest values belong to the Central (21.29\%), Volga $(18.83 \%)$ and Siberian $(14.65 \%)$ federal districts . The lowest value of the final indicator among the federal districts in the South $(6.31 \%)$ and North Caucasian (4.94\%).

A comparative assessment of the development level of the information and telecommunications sector of the regions is carried out taking into account the maximum value of the aggregate indicator. According to the assessment, the leading place in terms of the consolidated indicator in the Russian Federation is occupied by the Central and Volga federal districts, the Southern Federal District is significantly remote from the leader. 


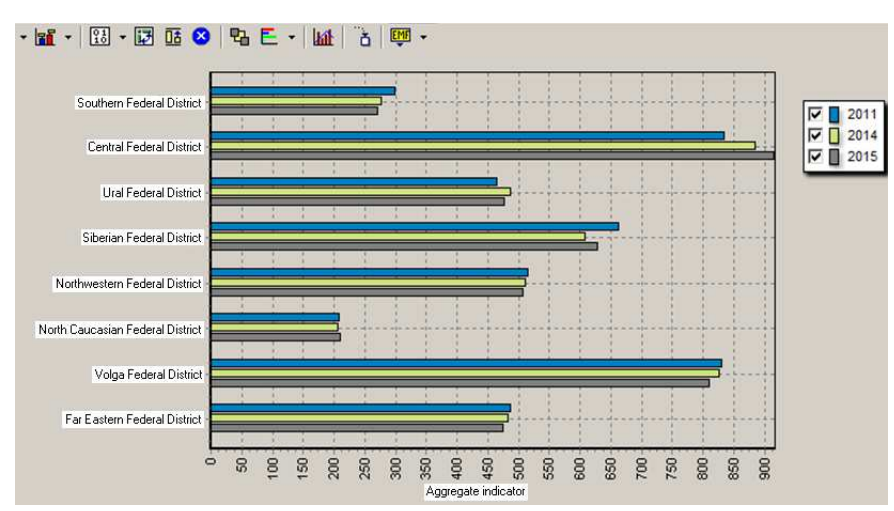

Fig. 5. Aggregate indicator of the level of development of the information and telecommunications sector by federal districts in the Russian Federation

Regions of the Southern Federal District for the analyzed period did not achieve significant progress on monitoring indicators of the development of the information and telecommunications sector, positive dynamics was observed only in the Rostov region (Figure 6).

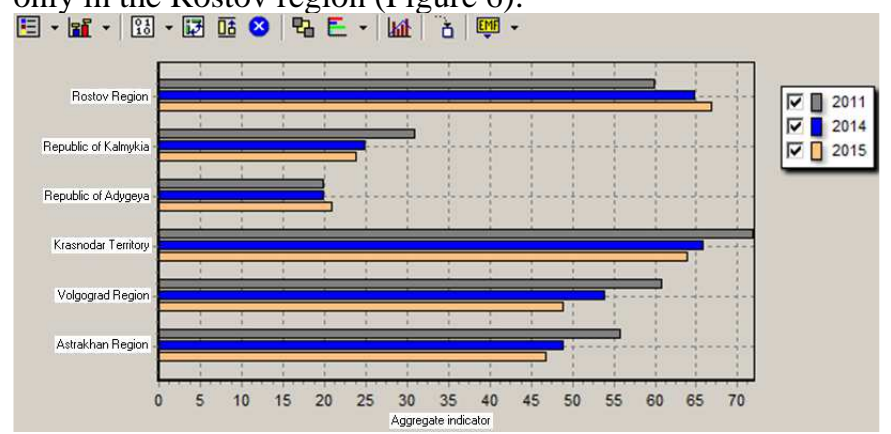

Fig. 6. Aggregate indicator of the development level of the information and telecommunications sector in the Southern Federal District

As a result of the analysis, the regions of the Russian Federation in terms of the value of the aggregate indicator in 2015 were typologized into 7 groups (Table 1).

"Leaders" are regions with the highest (maximum) level of development of the information and telecommunications sector $\left(\mathrm{I}_{\mathrm{AIi}} \geq 85\right)$. For this group of regions, the greatest degree of ICT use and formation of the basis for their functioning is characteristic, as well as the orientation towards the creation and promotion of high-level technologies of novelty.

"Potential leaders" are regions with a high level of development of the information and telecommunications sector $\left(74 \leq \mathrm{I}_{\mathrm{AIi}}<85\right)$. This group also has a high concentration of resources in the operation and use of ICT, which is necessary to ensure the development of the economy. With the strengthening of positions in the field of ICT, the regions of the group have a real opportunity to move to the "Leaders" group.

"Developed" - regions by the level of development of the information and telecommunications sector above the average $\left(63 \leq \mathrm{I}_{\mathrm{Ali}}<74\right)$. For these subjects, a characteristic is the high role of ICT in the functioning of economies, the availability or increase in the potential of using telecommunications. It seems expedient to develop measures aimed at maintaining the positive dynamics of the development of the information and telecommunications sector.

TABLE I. Distribution of Russian regions by the level of development of the information and telecommunications sector for 2015

\begin{tabular}{|c|c|}
\hline $\begin{array}{l}\text { Number } \\
\text { of group }\end{array}$ & Regions \\
\hline 1 & «Lea \\
\hline \multicolumn{2}{|l|}{ Moscow. } \\
\hline 2 & «Potential leaders» (3 regions) \\
\hline \multicolumn{2}{|c|}{ St. Petersburg, Tyumen Region, Sverdlovsk Region. } \\
\hline & \\
\hline \multicolumn{2}{|c|}{$\begin{array}{l}\text { Khanty-Mansi Autonomous Area - Yugra, Republic of Tatarstan, } \\
\text { Irkutsk Region, Krasnoyarsk Territory, Khabarovsk Territory, } \\
\text { Nizhny Novgorod Region, Samara Region, Krasnodar Territory, } \\
\text { Republic of Bashkortostan, Chelyabinsk Region, Novosibirsk } \\
\text { Region. }\end{array}$} \\
\hline & «Developing» (17 regions) \\
\hline \multicolumn{2}{|c|}{$\begin{array}{l}\text { Rostov Region, Perm Territory, Yamal-Nenets Autonomous } \\
\text { Area, Sakhalin Region, Moscow Region, Voronezh Region, } \\
\text { Tyumen Region without Autonomous Area, Primorye Territory, } \\
\text { Saratov Region, Orenburg Region, Stavropol Territory, } \\
\text { Udmurtian Republic, Altai Territory, Tomsk Region, Kemerovo } \\
\text { Region, Tula Region, Murmansk Region. }\end{array}$} \\
\hline 5 & «Unsustainable» (30 regions) \\
\hline \multicolumn{2}{|c|}{$\begin{array}{l}\text { Omsk Region, Republic of Sakha (Yakutia), Kamchatka } \\
\text { Territory, Komi Republic, Magadan Region, Lipetsk Region, } \\
\text { Amur Region, Kaluga Region, Vologda Region, Chukotka } \\
\text { Autonomous Area, Belgorod Region, Yaroslavl Region, } \\
\text { Volgograd Region, Republic of Mordovia, Vladimir Region, } \\
\text { Tambov Region, Kaliningrad Region, Penza Region, Ulyanovsk } \\
\text { Region, Republic of Buryatia, Chuvash Republic, Arkhangelsk } \\
\text { Region, Republic of Mari El, Kursk Region, Ryazan Region, } \\
\text { Smolensk Region, Republic of Karelia, Astrakhan Region, } \\
\text { Republic of Altai, Trans-Baikal Territory. }\end{array}$} \\
\hline & «Problematic» (13 regions) \\
\hline \multicolumn{2}{|c|}{$\begin{array}{l}\text { Orel Region, Kirov Region, Republic of Khakassia, Pskov } \\
\text { Region, Novgorod Region, Bryansk Region, Republic of North } \\
\text { Ossetia - Alania, Ivanovo Region, Kostroma Region, Chechen } \\
\text { Republic, Tver Region, Leningrad Region, Republic of } \\
\text { Daghestan. }\end{array}$} \\
\hline 7 & «Outsiders» (8 regions) \\
\hline Irgan & $\begin{array}{l}\text { Ion, Republic of Tuva, Republic of Kalmykia, } \\
\text { Ingushetia, Karachayevo-Circassian Republic, } \\
\text { lkarian Republic, Republic of Adygeya, Jewish }\end{array}$ \\
\hline
\end{tabular}

"Developing" - regions with an average level of development of the information and telecommunications sector $\left(53 \leq \mathrm{I}_{\mathrm{Ali}}<63\right)$. In the regions, there have been some achievements in the use of ICT, but generally insufficient for widespread use.

For these regions, development of measures aimed at intensifying the positive dynamics of the development of the information and telecommunications sector is required.

"Unsustainable" - regions with a level of development of the information and telecommunications sector below the average $\left(42 \leq \mathrm{I}_{\mathrm{AIi}}<53\right)$ and characterized by a high degree of 
instability. Within this group, the level of development of telecommunications is insufficient to form an innovative economy of the region and there is a need to find ways to improve their use and intensify activities aimed at increasing the role of ICT in the region's economy. The development of the regions of this group can be significantly influenced by the favorable external impact and the use of practices of more developed regions.

"Problematic" are lagging regions with a low level of development of the information and telecommunications sector $\left(31 \leq \mathrm{I}_{\mathrm{AIi}}<42\right)$. Regions included in this group have low values for almost all indicators of the allocated blocks. We believe that such relatively low positions of the regions can be explained by the lack of an innovative orientation of the economy. This direction can be realized due to the creation of an intellectual info-technology environment of the region.

"Outsiders" - in our interpretation these are the lagging regions, which have an extremely low level of development of the information and telecommunications sector $\left(\mathrm{I}_{\mathrm{AIi}}<31\right)$. It should be noted that this group is distinguished by the constancy of its composition. In this group of regions, there is a significant lag in the development of the ICT sector compared to other regions, which requires the adoption of appropriate measures to stop negative trends. It is necessary to develop a system of measures aimed at identifying the reasons for the backlog and increasing the potential of using information and communication technologies.

In the grouping of the regions of the Russian Federation for 2011 and 2015 there were no significant changes: 46 regions remained in the same rating group. In general, in 2015 compared to 2011,15 regions moved to a lower rating group; while 19 regions moved to a higher group, that is, there are positive trends in the development of the information and telecommunications sector.

\section{CONCLUSION}

The analysis made it possible to distinguish the following:

1) Insufficiently high level of development of the information and telecommunication component of the economy of the subjects of the Russian Federation. The calculations showed that a high level of interregional differentiation is maintained in terms of the volume of investments directed to the development of the information and telecommunications infrastructure and new types of services. When assessing the administrative-territorial units for the factors considered, the leader's aggregate indicator is 45 times higher than the indicator of the group of regionsoutsiders.

At present, there are still certain differences between the developed regions and those regions that have not yet fully mastered all the new technological and infrastructural opportunities that information and telecommunication technologies create.
2) The low level of basic skills in using information and telecommunication technologies in most regions. Changes in the quality of human capital imply the fulfillment of a number of conditions for the modernization of the social environment, the elimination of disproportions in the sphere of education (the increase in the number of students in higher education educational institutions and the reduction in the number of secondary specialized education), including activities to develop an ICT education system.

3) Relative stability of the selected types of regions. The grouping of Russian regions in terms of the level of development of the information and telecommunications sector has shown the relative constancy of the distribution structure by rating groups, there is a significant lag in most regions of the North Caucasian and Southern Federal District (with the exception of the Stavropol and Krasnodar Territories, Rostov and Volgograd regions). Weak positions on the level of development of the information and telecommunications sector are due to the low synergy of technological and innovative development of territorial units, insignificant dependence of the defining sectors of the economy on the level of development of information and telecommunication technologies.

The received analytical results can be used at differentiation of actions of authorities in view of features and restrictions of development of territories of the Russian Federation.

\section{References}

[1] Resolution of the Government of the Russian Federation of April 15, 1943 No. 313 "On approval of the state program of the Russian Federation" Information Society (2011-2020)". - Access mode: http://www.consultant.ru/document/cons_doc_LAW_162184/ (date of the application 10.01.2018).

[2] Order of the Government of the Russian Federation of 01.11.2013 No. 2036-r "Strategy for the development of the information technology industry in the Russian Federation for 2014-2020 and for the future until 2025". - Access mode: http://www.consultant.ru/cons/cgi/online.cgi?req=doc\&base=LAW\&n= $154161 \&$ rnd $=238783.2280818907 \& d s t=100009 \&$ fld $=134 \# 0$ (date of the application 12.01.2018).

[3] Order of the Government of the Russian Federation of 08.12.2011 No. 2227-r "On the Approval of the Strategy for Innovative Development of the Russian Federation for the Period to 2020". - Access mode: http://www.consultant.ru/cons/cgi/online.cgi?req=doc\&base=LAW\&n= $154161 \& \mathrm{rnd}=238783.2280818907 \& \mathrm{dst}=100009 \& \mathrm{fld}=134 \# 0 \quad$ (дата обращения 12.01.2018).

[4] Regions of Russia. Socio-economic indicators. 2016: stat. Sat. Moscow: Rosstat, 2016 [Electronic resource]. URL: http://www.gks.ru/free_doc/doc_2017/region/reg-pok17.pdf (date of the application 10.11.2017).

[5] Decree of the President of the Russian Federation of 09.05.2017 No. 203 "On the Strategy for the Development of the Information Society in the Russian Federation for 2017-2030" [Electronic resource]. URL: http://www.consultant.ru/cons/cgi/online.cgi?req=doc\&base=LAW\&n= $216363 \&$ fld $=134 \& \mathrm{dst}=1000000001,0 \& \mathrm{rnd}=0.12377674579797704 \# 076$ 41419808341328 (date of the application 12.01.2018). 